\title{
Island-encapsulating aeolian sedimentary systems of the Canary and Cape Verde Archipelagos
}

Hernández Calvento, L., Jackson, D. W. T., Cooper, A., \& Pérez-Chacón, E. (2017). Island-encapsulating aeolian sedimentary systems of the Canary and Cape Verde Archipelagos. Journal of Sedimentary Research, 87(2), 117-125. https://doi.org/10.2110/jsr.2017.6

Link to publication record in Ulster University Research Portal

\section{Published in:}

Journal of Sedimentary Research

\section{Publication Status:}

Published online: 07/02/2017

DOI:

10.2110/jsr.2017.6

\section{Document Version}

Author Accepted version

\section{General rights}

Copyright for the publications made accessible via Ulster University's Research Portal is retained by the author(s) and / or other copyright owners and it is a condition of accessing these publications that users recognise and abide by the legal requirements associated with these rights.

\section{Take down policy}

The Research Portal is Ulster University's institutional repository that provides access to Ulster's research outputs. Every effort has been made to ensure that content in the Research Portal does not infringe any person's rights, or applicable UK laws. If you discover content in the Research Portal that you believe breaches copyright or violates any law, please contact pure-support@ulster.ac.uk. 


\section{Island-encapsulating aeolian sedimentary systems of the Canary}

\section{and Cape Verde Archipelagos}

\section{Luis Hernández Calvento ${ }^{1}$; Derek W. T. Jackson ${ }^{2}$; Andrew Cooper ${ }^{2,3}$, Emma Pérez-Chacón ${ }^{1}$}

${ }^{1}$ Grupo de Geografía Física y Medio Ambiente. Instituto de Oceanografía y Cambio Global, IOCAG, Universidad de Las Palmas de Gran Canaria, ULPGC, Parque Científico Tecnológico Marino de Taliarte, 35214 Telde, Spain. Email: luis.hernandez.calvento@ulpgc.es; eperez@dgeo.ulpgc.es

${ }^{2}$ Environmental Sciences, University of Ulster, Cromore Road, Coleraine, Northern Ireland, UK, BT52 1SA. Email: d.jackson@ulster.ac.uk; jag.cooper@ulster.ac.uk

${ }^{3}$ School of Agriculture, Earth and Environmental Sciences, University of KwaZulu-Natal, Private Bag X54001, Durban, South Africa

\section{ABSTRACT}

Aeolian dunes are generally absent or poorly developed on oceanic islands. Yet, large-scale aeolian sedimentary systems characterize the oceanic islands of the Canary and Cape Verde archipelagos. These island-encapsulating sedimentary systems extend around or across entire islands and comprise upwind source areas, aeolian transport corridors and downwind sediment depocentres, each of which is characterised by distinctive dune forms. Upwind beaches are denuded of sand, while downwind locations exhibit progressive shoreline accretion. Cross-island transport corridors developed in topographic lows on the island surface are characterised by a variety of landforms including sandsheets, barchanoid dunes and transverse dunefields, depending on topography and local sediment volume and supply. Circumisland transport corridors develop when the island topography is high and sediment transport takes place on the island margins, alternating between headland-bypass dunes and longshore transport in the littoral zone in the intervening embayments. Depocentres comprise extensive aeolian dunefields, prograding 
24 beaches or beach ridges depending on local topography. Recognition of the interconnected nature of the 25 components of these contemporary systems has important management implications.

26 The presence of these sedimentary systems in the Canary and Cape Verde chains can be attributed to a

27 particular combination of geological and geographical factors. The thick lithosphere in which the island

28 chains occur slows subsidence rates and creates long-lived oceanic islands that are exposed to weathering

29 and erosion for several million years during which terrestrial denudation and biogenic sediment

30 production creates a sufficient volume of littoral sediment. From a geographical perspective, these islands

31 are in arid or semi-arid environments with unidirectional or strongly asymmetrical transport-capable

32 winds (i.e. Trade Winds).

\section{INTRODUCTION}

34 Although there are many large scale coastal aeolian dune accumulations in continental settings, a global

35 review shows them to be rare on oceanic islands. The isolated nature of a volcanic island and surrounding

36 very deep water means that littoral sand can only originate locally by (i) denudation and erosion of the

37 islands themselves; and (ii) accumulation of biogenic sediment from the remains of marine organisms that

38 inhabit the island margins.

39 Post-eruption subsidence means that most oceanic islands remain emerged for $<5 \mathrm{My}$ (after their initial 40 formation (Carracedo and Tilling, 2003). This limits the time available for sediment production. Islands

41 in rigid oceanic lithosphere, however, have low subsidence rates and may remain emerged for $>20$ My.

42 Long exposure to weathering and erosion promotes the development of marginal platforms, which retain

43 terrigenous sand and provide an environment amenable to colonization by calcifying marine organisms.

44 This sediment supply provides the potential for developing extensive littoral and aeolian deposits (Alonso 45 et al., 2011; Criado et al., 2011).

46 In this paper we describe the large-scale coastal dune systems of the Canary and Cape Verde island 47 chains. Uniquely among oceanic islands, active sedimentary systems traverse entire islands, moving sand 
48 from source to sink via distinctive transport pathways producing a hitherto undescribed type of dune 49 system. Several examples are detailed below.

\section{METHODS}

52 A global review of the nature and distribution of coastal dunes on oceanic islands was conducted using 53 historical and contemporary aerial photography, satellite images and published sources, as well as via

54 fieldwork. Photos of the Canary and Cape Verde island chains were obtained from the governmental 55 spatial data infrastructures (SDI) of the Canary Islands (www.idecanarias.es) and Cape Verde 56 (http://www.idecv.gov.cv/), and from the ULPGC archives (Departamento de Geografía and Grupo de

57 Geografía Física y Medio Ambiente). Together with Google Earth, these images (Table 1) were used to 58 identify and classify aeolian landforms and track temporal changes. Fieldwork in the Canary Islands has 59 been ongoing since 2002, whilst fieldwork campaigns were undertaken in Cape Verde in 2005 and 2009.

60

61

62

63

64

65

66

67

68

69

70

71

\section{RESULTS}

\section{Cape Verde Islands}

The Cape Verde Archipelago $\left(14^{\circ}-18^{\circ} \mathrm{N} 22^{\circ}-26^{\circ} \mathrm{W}\right.$ (Figure 1) comprises two island chains generated by Neogene oceanic volcanism. The islands are between 20 million (eastern sector) and 8 million years old. The islands are located within the Sahelian arid belt with average annual rainfall $<200 \mathrm{~mm} \mathrm{yr}^{-1}$ (Ramalho, 2011). Winds are predominantly from the NNE (Figure 1 insert). The main aeolian sedimentary fields in the Canary Islands are shown in Figure 2 (Modified from Alonso et al., 2011), which demonstrates the spatial variety and form differences found across the region.

\section{Boa Vista}

On Boa Vista large outcrops of Quaternary carbonate aeolianite form 100-m high, platforms. 1 Contemporary aeolian processes rework these aeolianites plus contemporary carbonate sands into coastal 
72 and inland dunes. Sediment dynamics of Boa Vista are characterized by distinct transport pathways 73 between the north and south of the island (Hernández-Calvento and Suárez, 2006). Sediment is 74 transported by wind across low, unobstructed parts of the coast. Nebkha dunes (Figure 3A) in the source 75 zone form around isolated vegetation patches immediately at the rear of the beach and individual 76 hummocks are typically 1-2 m high and 2-3 m diameter. They often have a downwind 'tail' or 'shadow

77 dune' form (Figure 3A). Cross-island transport occurs in sand sheets with occasional barchan dunes and 78 barchanoid ridges (Figure 3B). Localized sediment accumulations within the transport corridor result in 79 development of transverse ridges with linear crest lines (Figure 3C). Sediment transport occurs in a 80 largely unbroken NE-SW direction with the sediment pathway dictated by local topography. These are 81 noted as moving at rates between $9.11 \mathrm{~m} \mathrm{year}^{-1}$ up to $27.69 \mathrm{~m} \mathrm{year}^{-1}$ (1991-2015) (Figure 4 and table 2).

82 At the coast, transport is observed to alternate between aeolian and nearshore wave-driven regimes 83 (Figure. 5). On the downwind island margin sediment accumulates as a wide sandy beach backed by 84 beachridges, indicating long-term progradation (see Figure 3D).

85

\section{The Canary Islands}

87 The Canary Islands Archipelago (27 $37^{\prime}-29^{\circ} 25^{\prime} \mathrm{N}, 13^{\circ} 20^{\prime}-18^{\circ} 10^{\prime} \mathrm{W}$ ) (figure $2 \mathrm{~A}$ ) is located on the 88 African Plate, on oceanic crust of Jurassic age (165-176 My). The crust is among the oldest and most 89 rigid on the planet, causing slow subsidence (Carracedo et al., 2002). The development of the island chain 90 can be divided into several stages involving initial eruption and island formation, a resting phase when 91 erosive processes dominate, a stage of rejuvenation, and a final stage of simultaneous volcanism and 92 erosion, in which erosion gradually dominates to result in complete disappearance of the islands 93 (Carracedo, 1999, Carracedo and Tilling, 2003).

94 The age of the islands increases eastward, with the oldest being Lanzarote and Fuerteventura (15-20 My), 95 (Carracedo and Tilling, 2003). Fuerteventura and Lanzarote, share the same volcano. A wide shelf in the 96 east promotes biogenic productivity on these islands. During phases of marine regression these sandy 
97 deposits are mobilised by NE Trade Winds (Figure 1 insert) and generate large dune fields in the

98 prevailing arid conditions (Criado et al., 2011; Alonso et al., 2011). When the topography is low, coastal

99 sand is blown inland as sand dunes or sandsheets. Dunefields migrate parallel to the direction of the trade

100 winds, but can be modified by local topography (Cabrera Vega, 2010; Jackson et al, 2013 ${ }_{\mathrm{a}, \mathrm{b}, \text { ). Large }}$

101 aeolian deposits dominate in the eastern islands whereas in the western Islands, cliffs cause only isolated

102 climbing-dunes to form (Criado et al. 2011).

103 Quaternary aeolian systems reached altitudes of around 200 m (Meco et al., 2002). These older deposits 104 have since cemented to form aeolianites (Torres, 1995) some of which are being reworked by 105 contemporary wind action to yield sediment for the modern aeolian system. Examples of these dune 106 systems occur at Jandía (Fuerteventura) (Figure 2B) and El Jable (Lanzarote) (Figure 2C).

\section{Jandia (Fuerteventura)}

108 The Jandía aeolian field (Figure 2B) extends across the island of Fuerteventura. Its contemporary $55 \mathrm{~km}^{2}$ 109 dune system is developed by reworking of the surface of a Quaternary aeolianite that rests on a Miocene 110 volcanic substrate. Two calcrete horizons within the aeolianite dated at $13.8 \mathrm{Ka}$ and $9.8 \mathrm{Ka}$ (Rognon et 111 al., 1989) indicate emplacement during early Holocene low sea levels. The upwind margin of the 112 aeolianite field and the underlying basalt has been wave-eroded to form a $30 \mathrm{~m}$-high sea cliff. This 113 precludes any significant contemporary sediment input from the littoral zone (Alcantara-Carrio, 2003). 114 Contemporary aeolian deposits comprise sand sheets and reversing dunes in the upwind source area with 115 shadow dunes in the interior of the dunefield. The terminus of aeolian activity is found on the SE 116 (downwind) side of the island where a wide prograding sandy beach has developed.

\section{EI Jable (Lanzarote)}

118 This $21 \mathrm{~km}$-long aeolian system (Figure 2C) occupies a total area of $90 \mathrm{~km}^{2}$. It is gently sloping but rises 119 to $200 \mathrm{~m}$ in places. Aeolian phases occurred throughout the Quaternary (Meco et al., 2002). 120 Contemporary aeolian activity is now restricted to only a small section at the NE part of the island at 121 Playa de Famara. Here, nebkhas at the coastal fringe give way to a southward migrating sand sheet within 
122 which some barchan dunes are migrating at $>20 \mathrm{~m} /$ year (Cabrera Vega, 2010). Agriculture, mining, and 123 other human activities have inhibited aeolian transport (Cabrera Vega, 2010; Cabrera Vega et al., 2013).

\section{Conceptual model}

125 An oceanic island-encapsulating dune system is characterised by three main zones: source, transport 126 corridor and sink (Figure 6). The source area on the upwind side of the island usually comprises a narrow 127 sand beach backed by a zone of hummock dunes (also known as nebkhas or coppice dunes) and a sand 128 sheet.

129 Sand that blows through the hummocky dune zone continues landward as sand sheets lacking in 130 vegetation. Localized accumulations of sand in this inland zone form barchans that migrate as discrete 131 forms and occasionally, large accumulations of wind-blown sand create fields of transverse dunes.

132 An alternative to cross-island sand transport occurs when the sand is blown around the margin of the 133 island. In such instances, the transport corridor consists of alternating headland-bypass dunes and 134 embayed beaches with littoral drift following the aeolian transport corridor. Aeolian sand passes from the 135 dune to beach and back again several times as it circumnavigates the island.

136 At the downwind side of the island, dunes migrate seawards, returning the sand to the littoral zone (Short 137 and Jackson, 2013) and creating prograding beaches (e.g. Fuerteventura), multiple beachridges (Boa 138 Vista) or subtidal sediment accumulations (Lanzarote). Whether the dune system takes an overland or 139 circum-coastal route depends on the local topography. Topography also induces variability in the source 140 and depositional zones. If the depositional area consists of a cliff, sediment flows into the ocean and

141 accumulates subtidally (e.g. Lanzarote) on the shoreface (Backstrom et al. 2009). If a low-lying area is 142 present, the sand accumulates as a prograding beach.

143 Quaternary island-encapsulating dune systems are evidenced by aeolianite whose distribution sometimes 144 mimics the contemporary aeolian landforms in the Canary and Cape Verde archipelagos. In many 
instances weathering of the upper surface of Quaternary aeolianites liberates formerly bound sand grains

146 that re-enter the sedimentary system.

\section{DISCUSSION}

148 The aeolian systems described here involve the transport of large volumes of littoral sediment across

149 and/or around entire hot spot volcanic oceanic islands in appropriate settings and stages of development.

150 They require several conditions:

- Adequate sand supply (contemporary sources or wind-reworking of Quaternary sand)

- A uni-directional (or strongly asymmetrical) wind field (all occur in trade wind locations)

- Arid conditions (more humid conditions encourage vegetation growth and inhibit transgressive dune development)

The development of significant aeolian deposits on these oceanic islands requires prolonged periods of erosion with attendant biogenic productivity to create the necessary sediment. Encapsulating dune

157 systems are thus restricted to mature volcanic islands that persist due to low subsidence rates. They represent a distinctive geological phase of evolution in such island systems. Our global review shows coastal dunes to be very poorly developed or absent on most contemporary oceanic islands. This, in turn points to the existence of globally unique conditions in the study sites considered here. Chief among these conditions is the longevity of the archipelagos - both are located in areas of thick and slowly

162 subsiding crust. We suggest that this element is critical in providing sufficient time to develop an original 163 sediment volume (though weathering, erosion and biogenic productivity) capable of subsequent transport 164 and re-distribution by wind.

The systems described bear some similarity to headland-bypass dunes (Boeyinga et al., 2010), 166 however, they encompass entire islands and may traverse several topographic highs or alternating aeolian 167 and wave transport phases. Transport pathways are determined by local relief and they may cross or 168 circumscribe the island. 
Human activities can impact severely on interconnected aeolian systems, modifying the natural

170 processes or inhibiting them. Land use changes, especially due to urban development, have played an

171 important role in the geomorphological and functional changes in the dune fields of the Canary Islands.

172 Santana Cordero et al. (2016a) show how traditional human activities remobilized the dunefield of La

173 Graciosa. In contrast, the same authors explain how urban expansion of the city of Las Palmas de Gran

174 Canaria, has destroyed the dunefield of Guanarteme (Santana Cordero et al., 2006b). García-Romero et al.

175 (2016) relate changes in some aeolian sedimentary systems of the Canary Islands to urban-touristic

176 development. Other authors have examined direct or indirect changes in aeolian sedimentary landforms,

177 by mining or construction on parts of the dunefields themselves (Cabrera Vega, 2010; Alonso et al., 2011;

178 Cabrera-Vega et al., 2013; Hernández-Calvento et al., 2014).

179 Taking into account the model presented in this paper, the alteration of any of these dune 180 components can impact on those parts of the system located downwind, altering both beach and dune 181 phases. This is especially relevant in those islands where touristic development is currently expanding 182 such as in Cape Verde.

\section{Conclusion}

Development of substantial aeolian dunes is a distinctive evolutionary phase of some oceanic island chains. The dunes are transported in the direction of net aeolian drift and form sedimentary systems that encapsulate entire islands. Understanding the sedimentary system of an entire island as a single

187 system has important implications for development.

\section{Acknowledgements}

This work is a contribution to the projects CSO2010-18150 and CSO2013-43256-R funded by the

R\&D+ I (innovation) Spanish National Programme, co-financed with ERDF funds. We are grateful to 191 Irene Delgado-Fernández and an anonymous reviewer for their constructive comments and suggestions. 


\section{Figure Captions}

194 Figure 1. Location of the Canary and Cape Verde Islands. Inserts show predominant wind directions at 195 both sites.

196 Figure 2. A) location and classification of the main aeolian sedimentary fields in the Canary Islands 197 (modified from Alonso et al., 2011). Red circles identify the dune fields of Jandía (Fuerteventura) and El 198 Jable (Lanzarote), showed in 2B) and C) respectively. White arrows indicate the direction of the 199 sedimentary transport. D) Playa de Jandía (SE): leaking dunes (falling dunes) and beach. E) Playa de 200 Famara (N El Jable) accretionary dunes (hummock) and human interferences (by urban area).

201 Figure 3. Various dune types; A) Hummocks N shore Boa Vista; B) Barchans migrating across Boa 202 Vista; C) Deserto de Viana, Boa Vista; D) sediment accumulation in the form of a wide sandy beach 203 backed by beachridges, indicating long-term progradation.

204 Figure 4: Displacement rates of barchan dunes and barchanoid ridges at Chave (W Boa Vista), top row, 205 and Santa Monica (SW Boa Vista), lower row, between 1991 and 2015, calculated following the method proposed by Gay (1999). Red lines (left) are the brinks in 1991, identified by photo-interpretation; blue

207 lines (center) are the brinks in 2015. The red straight vectors (right) indicate the distance between brinks 208 (in each dune). This distance, divided by the number of years, provides the rates (m year ${ }^{-1}$ )

209 Figure 5. Aeolian sand passes from the dune to beach and back again several times as it circumnavigates the island (Boa Vista)

211 Figure 6. Conceptual model of an island-encapsulating dune system showing the two possible routes that

212 large sediment transport systems may take on encountering volcanic islands. The overland scenario (1) 213 results in several dune types as the sediment migrates over the land surface from one side of the island to 214 the next following a largely linear direction. The circum-island route (2) involves successive littoral and 215 terrestrial transport phases to eventual encapsulate the island as it transfers sediment around the island. 


\section{REFERENCES}

Alonso, I., Hernández, L., Alcántara-Carrió, J., Cabrera Vega, L.L., Yanes, A., 2011. Los grandes campos de dunas actuales de Canarias. In: Sanjaume, E. and Gracia, J. (eds), Las dunas en España, 467-496.

Backstrom, J.T., Jackson, D.W.T. and Cooper, J.A.G. 2009. Shoreface morphodynamics of a highenergy, steep and geologically constrained shoreline segment in Northern Ireland. Marine Geology 257 (1), 94-106.

Boeyinga, J., Dusseljee, D.W., Pool, A.D., Schoutens, P. Verduin, F., van Zwicht, B.N.M., and Klein, A.H.F. 2010. The effects of a bypass dunefield on the stability of a headland bay beach: A case study. Coastal Engineering, 57 (2), 152-159.

Cabrera Vega, L.L. 2010. Sedimentología, estratigrafía, dinámica sedimentaria y evolución de El Jable (Lanzarote). Propuesta de gestión. PhD Thesis. Facultad de Ciencias del Mar. ULPGC.

Cabrera-Vega, L.L., Cruz-Avero, N., Hernández-Calvento, L., Hernández-Cordero, A.I., FernándezCabrera, E., 2013. Morphological changes in dunes as indicator of anthropogenic interferences in arid dune fields. Journal of Coastal Research SI 65: 1271-1276.

Carracedo, J.C. 1999. Growths, structure, instability and collapse of Canarian volcanoes and comparisons with Hawaiian volcanoes. Journal of Volcanology and Geothermal Research, 94: 1-19.

Carracedo, J.C., Pérez, F.J., Ancochea, E., Meco J., Hernán, F., Cubas C.R., Casillas, R., Rodriguez, E., Ahijado, A., 2002. Cenozoic volcanism II: The Canary Islands. In Gibbons, W., Moreno, T. (eds.) The Geology of Spain. The Geological Society of London, London, 439-472.

Carracedo, J.C., Tilling, R.I. 2003. Geología y volcanología de islas volcánicas oceánicas (CanariasHawaii). Servicio de Publicaciones de la Caja General de Ahorros de Canarias, 73 p.

Criado C., Yanes A., Hernández Calvento L., Alonso I., 2011. Origen y formación de los depósitos eólicos en Canarias. In Sanjaume E. and Gracia F.J (eds.): Las dunas en España. Sociedad Española de Geomorfología, Madrid, 447-465. 
241 García-Romero, L., Hernández-Cordero, A.I., Fernández-Cabrera, E., Peña-Alonso, C., Hernández-

242 Calvento, L., Pérez-Chacón, E., 2016. Urban-touristic impacts on the aeolian sedimentary systems of the

243 Canary Islands: conflict between development and conservation. Island Studies Journal 11 (1): 91-112.

244 Gay, S.P., 1999. Observations regarding the movement of barchan sand dunes in the Nazca to Tanaca 245 area of Southern Peru, Geomorphology 27: 279-293.

246 Hernández-Calvento, L., Suárez, C., 2006. Characterization of the contemporary aeolian sediment 247 dynamics of Boa Vista (Cape Verde). Journal of Coastal Research SI 48, 64-68.

248 Hernández-Calvento, L., Jackson, D.W.T., Medina, R., Hernández-Cordero, A.I., Cruz, N.; Requejo, S., 249 2014. Downwind effects on an arid dune field from an evolving urbanised area. Aeolian Research 15: $250 \quad 301-309$.

251 Jackson, D.W.T., Cruz-Avero, N., Smyth, T., Hernandez-Calvento, L. 2013a. 3D airflow modelling and 252 dune migration patterns in an arid coastal dune field. Journal of Coastal Research, SI 65. pp. 1301-1306.

253 Jackson, D.W.T., Beyers, M., Delgado-Fernandez, I. Baas, A.C.W., Cooper, J.A.G., Lynch, K. 2013 254 Airflow reversal and alternating corkscrew vortices in foredune wake zones during perpendicular and 255 oblique offshore winds. Geomorphology, 187, 86-93.

256 Meco, J., Guillou, H., Carracedo, J.C., Lomoschitz, A., Ramos, A.J.G. and Rodriguez-Yánez, J.J. 2002. 257 The maximum warmings' of the Pleistocene world climate recorded in the Canary Islands. 258 Palaeogeography, Palaeoclimatology,Palaeoecology, 185 (1-2): 197-210.

259 Ramalho, R. A. S. 2011. Building the Cape Verde Islands, 1st ed., Springer, Berlin, Heidelberg.

260 Ramalho, R. A. S., Brum da Silveira, A., Fonseca, P. E., Madeira, J., Cosca, M. Cachao, M. Fonseca, M., 261 Prada, S. N. 2015. The emergence of volcanic oceanic islands on a slow-moving plate: The example of 262 Madeira Island, NE Atlantic, Geochem. Geophys. Geosyst., 16, doi:10.1002/2014GC005657. 
263 Rognon, P., Coudé-Gaussen, G., Le Coustumer, M.N., Balouet, J.C., Occhietti, S. 1989. Le massif 264 dunaire de Jandia (Fuerteventura, Canaries): Ëvolution des paléoenvironements de 20000 BP à l'actuel. 265 Bulletin de l'Assocation française pour l'étude du Quaternaire 1, 31-37.

266 Santana-Cordero, A., Monteiro-Quintana, M.L., Hernández-Calvento, L.; Pérez-Chacón Espino, E.; 267 García Romero, L., 2016a. Long-term human impacts on the coast of La Graciosa, Canary Islands. Land 268 Degradation \& Development 27: 479-489.

269 Santana-Cordero, A.M., Monteiro-Quintana, M.L., Hernández-Calvento, L., 2016b. Reconstruction of the 270 land uses that led to the termination of an aridcoastal dune system: The case of the Guanarteme dune 271 system (Canary Islands, Spain), 1834-2012. Land Use Policy 55: 73-85.

272 Short A.D., and Jackson D.W.T. 2013. Beach Morphodynamics. In: John F. Shroder (ed.) Treatise on

273 Geomorphology, Volume 10, 106-129. San Diego: Academic Press.

274 Torres J.M. 1995. El suelo como recurso natural: Procesos de degradación y su incidencia en la 275 desertificación de la isla de Fuerteventura. PhD Thesis. Departamento de Edafología y Geología de la 276 Universidad de La Laguna. 
Table 1. Photos and images used

\begin{tabular}{|c|c|c|c|c|}
\hline Place & Date & Source & Class & $\begin{array}{l}\text { Scale / spatial } \\
\text { resolution }\end{array}$ \\
\hline \multirow{3}{*}{$\begin{array}{l}\text { Canary Islands } \\
\text { (Fuerteventura } \\
\text { and Lanzarote) }\end{array}$} & 1977, 1987 & ULPGC & Aerial photos & $1 / 18.000$ \\
\hline & $\begin{array}{l}\text { 1998, 2002, 2004, 2008, } \\
\text { 2009, 2011, 2012, 2013, } \\
\text { 2014, } 2015\end{array}$ & $\begin{array}{l}\text { SDI Canary } \\
\text { Islands }\end{array}$ & Orthophotos & $\begin{array}{l}1 / 5.000-1 / 18.000 \\
\text { (original aerial } \\
\text { photos) }\end{array}$ \\
\hline & $\begin{array}{l}2000,2003,2006,2007, \\
2015\end{array}$ & $\begin{array}{l}\text { Google } \\
\text { Earth }\end{array}$ & $\begin{array}{l}\text { Satellite images } \\
\text { and orthophotos }\end{array}$ & $\begin{array}{l}1 \mathrm{~m} / \text { pixel }-0.6 \\
\mathrm{~m} / \text { pixel }\end{array}$ \\
\hline \multirow{3}{*}{$\begin{array}{lr}\text { Cape } & \text { Verde } \\
\text { Islands } & \text { (Boa } \\
\text { Vista) } & \end{array}$} & 1991 & ULPGC & Aerial photos & $1 / 15.000$ \\
\hline & 2003 & $\begin{array}{l}\text { SDI Cape } \\
\text { Verde }\end{array}$ & Orthophoto & $\begin{array}{l}1 / 28.000 \text { (original } \\
\text { aerial photos) }\end{array}$ \\
\hline & $\begin{array}{l}\text { 2005, 2010, 2011, 2012, } \\
\text { 2013, 2015, } 2016\end{array}$ & $\begin{array}{l}\text { Google } \\
\text { Earth }\end{array}$ & $\begin{array}{l}\text { Satellite images } \\
\text { and orthophotos }\end{array}$ & $\begin{array}{l}1 \mathrm{~m} / \text { pixel }-0.6 \\
\mathrm{~m} / \text { pixel }\end{array}$ \\
\hline
\end{tabular}


Table 2: Maxima, minima and average displacement rates of the dunes of Boa Vista.

\begin{tabular}{|l|l|l|l|}
\hline \multirow{2}{*}{ Place } & \multicolumn{3}{|l|}{ Rate (m/year) } \\
\cline { 2 - 4 } & Max & Min & Average \\
\hline Chave (W) & 19.56 & 9.11 & 14.68 \\
\hline Santa Mónica (SW) & 27.69 & 10.30 & 19.73 \\
\hline
\end{tabular}



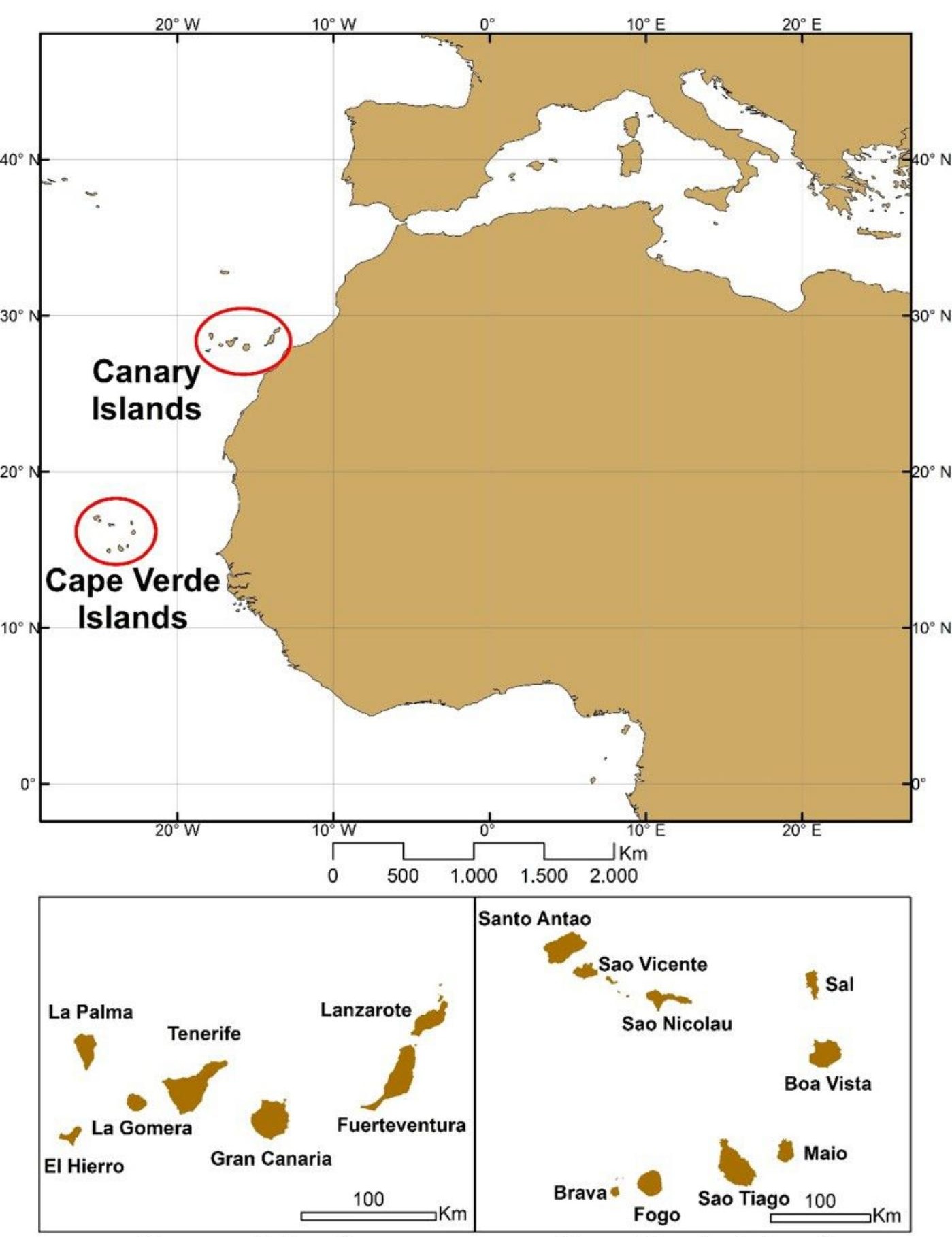

Canary Islands

Cape Verde Islands
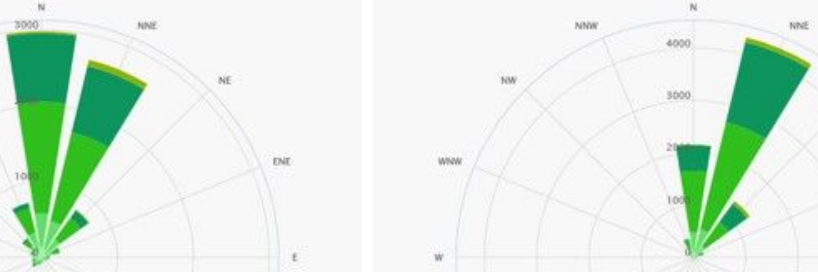


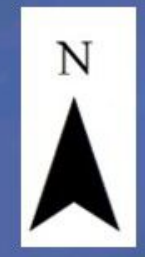

\section{Beach phase}

Sallebune phase

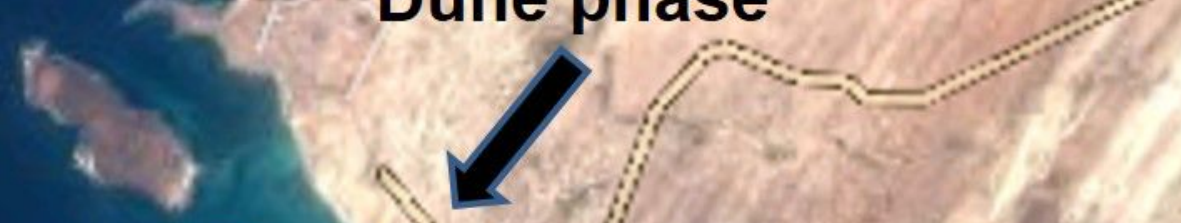

\section{Beach phase}

Beach phase

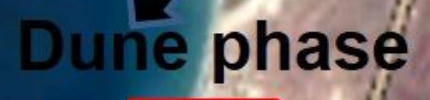

Dune phase

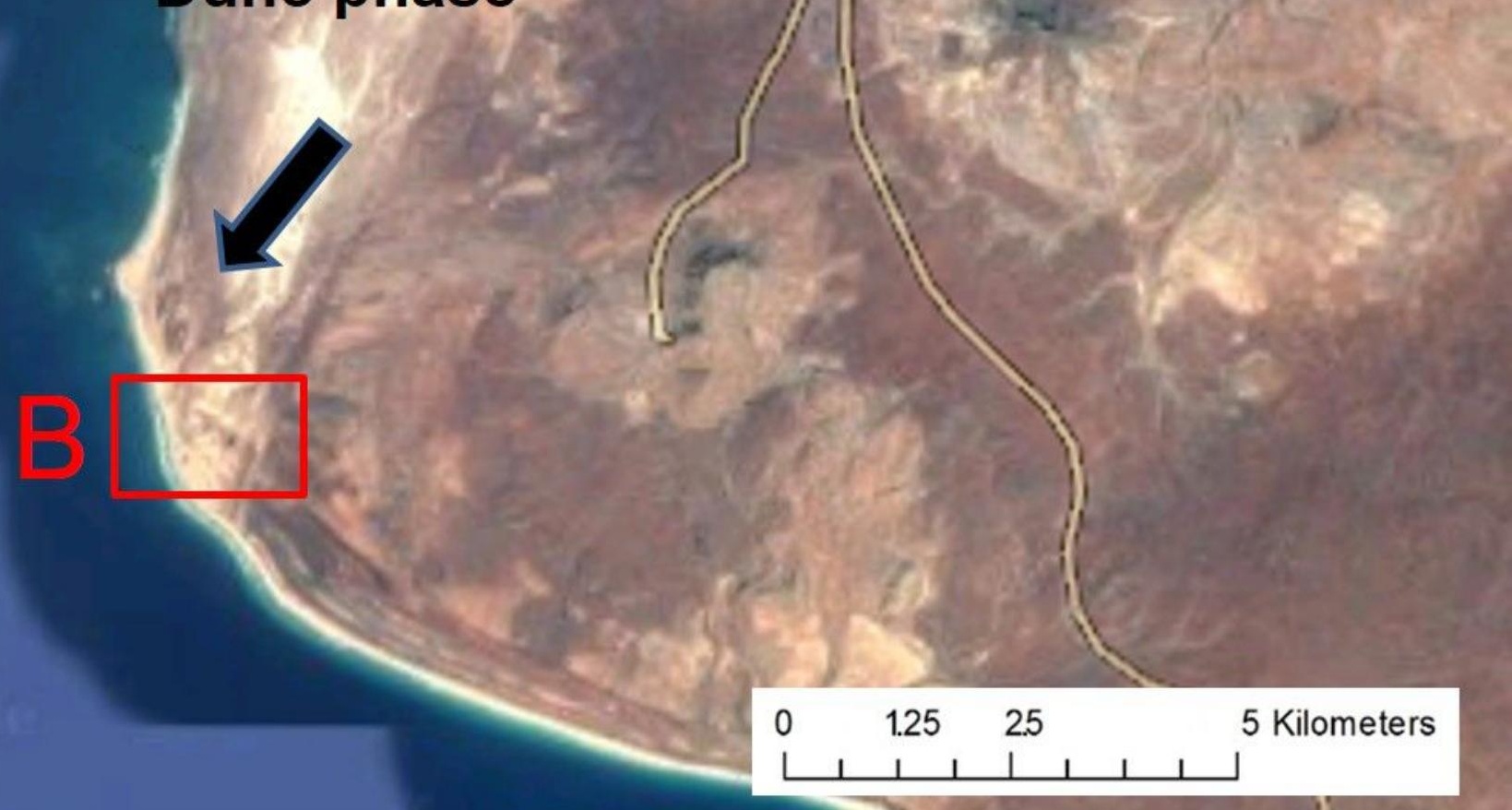


